\title{
PULAU PISANG LIGHT: A NON- MALAYSIAN LIGHTHOUSE ON A MALAYSIAN ISLAND
}

\author{
${ }^{1}$ Mohd Hazmi Mohd Rusli, ${ }^{2}$ Rahmat Mohamad \& ${ }^{3}$ Roman Dremliuga \\ ${ }^{1}$ Australian National Centre for Ocean Resources and Security (ANCORS), \\ University of Wollongong, Australia \& \\ Faculty of Syariah and Law, Universiti Sains Islam Malaysia \\ ${ }^{2}$ Faculty of Law, Universiti Teknologi MARA \\ ${ }^{3}$ School of Law, Far Eastern Federal University, \\ Vladivostok, Russia \\ (mhbmr027@uowmail.edu.au, dremliuga.ri@dvru.ru)
}

\begin{abstract}
Pulau Pisang is a small island situated off the western coast of the Malaysian state of Johor at the southern end of the Straits of Malacca. The island is about 12 kilometres from Pontian Kechil and 5 kilometres from the town of Benut and is the site of the Pulau Pisang Light, a lighthouse guiding ships into the western entrance of the busy Singapore Strait. From colonial times, the Pulau Pisang Light has always been recognised as within the territory of the independent Sultanate of Johor. The Sultanate of Johor became a British protectorate in the twentieth century and upon independence, Johor became one of the states within Malaysia. Currently, the lighthouse is managed and operated by the Maritime and Port Authority (MPA) of Singapore and the lighthouse precinct is off limits to Malaysians. This article examines the status of Pulau Pisang as an island under Malaysian sovereignty. This article further looks at the possible future implications should Singapore continue to manage the Pulau Pisang Light that instigates the question: Will Pulau Pisang become another Pedra Branca?
\end{abstract}

Keywords: Straits of Malacca and Singapore, Pulau Pisang Light, sovereignty, Pedra Branca, shipping

\section{Introduction}

The Straits of Malacca and Singapore are two of the busiest shipping ways in the world (Rusli, 2012a). There have been more than 70, 000 vessel movements in the 
Straits of Malacca and Singapore in 2010 and this figure is expected to increase twofold by the year 2020 (Rusli, 2012b). The importance of the Straits of Malacca and Singapore as important maritime conduits has been foreseen by the British government of the Straits Settlement in Singapore since the turn of the twentieth century.

In order to ensure smooth navigational movements of vessels, the British built a lighthouse in 1914 ("Pulau Pisang to be gazetted as part of Johor," 2010). For almost a century, the Pulau Pisang Light has functioned as an aid for maritime navigation into the western entrance of the Singapore Strait (Rusli \& Mohamad, 2013). Even though Pulau Pisang is under Malaysia's sovereignty, this is not entirely the case for the Pulau Pisang Light as it is manned by Singapore.

\section{Pulau Pisang Light}

This unique arrangement was created as a result of the agreement, signed between Sultan Ibrahim of Johor and the Governor of the Straits Settlements, Sir James Alexander Sweethenham, entered into in 1900 ("Ghani: Malaysia has proof of Pulau Pisang Ownership," 2008). This landmark agreement did not only manifest British acknowledgment of Johor's sovereignty over Pulau Pisang, but it also marked a momentous occasion whereby the Sultan of Johor granted the rights in perpetuity to the British to the plot of land on which the lighthouse stands and to the roadway leading to it (Lathrop, 2008; Singapore has no right to expand area around Pulau Pisang, says Johor MB, 2008).

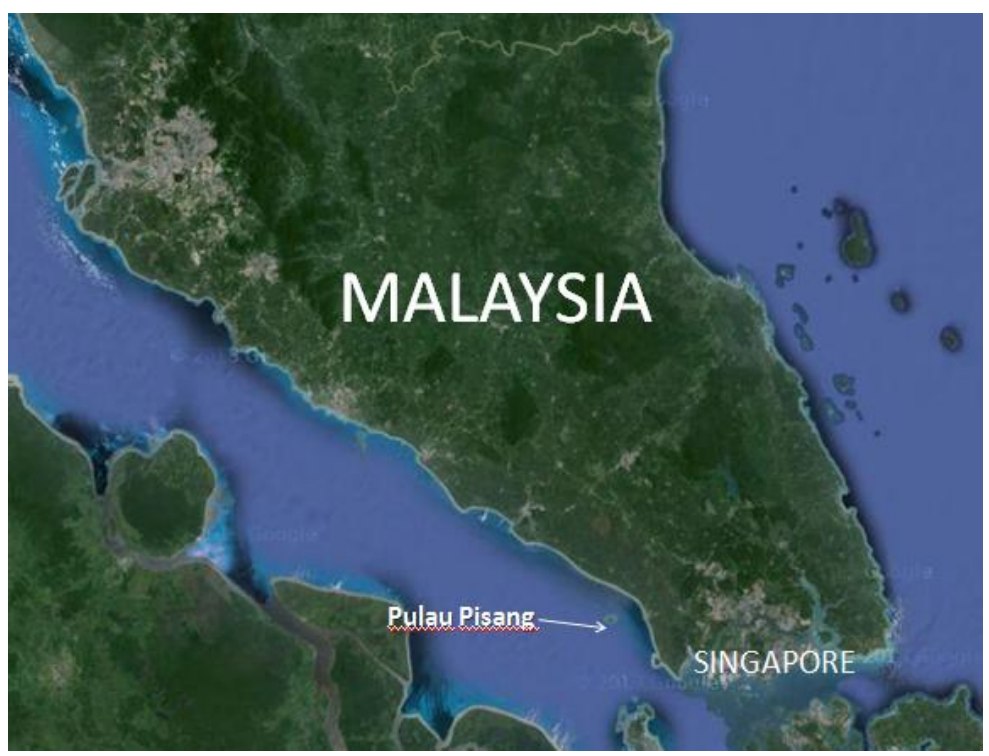

Figure 1: Location of Pulau Pisang

(Source: Modified from GoogleMaps) 
Upon the separation of Singapore from the Federation of Malaysia in 1965, it inherited the territory that forms the modern day Republic of Singapore under the international law concept of utti possidetis juris (Ryan, 1967). The responsibility to manage the lighthouse remains with Singapore and the Malaysian government has no intention to take over the management of the lighthouse from the MPA in the near future (Rusli \& Mohamad, 2013).

\section{Sovereignty over Pulau Pisang}

In 2003, the then Minister for Foreign Affairs of Singapore, Professor S. Jayakumar, mentioned to the Parliament of Singapore that the sovereignty over Pulau Pisang is with Malaysia (Singapore Parliament (Special Parliament Highlights, 9 May 2005), 2005). He also reiterated that Singapore has never disputed Malaysia's sovereignty over Pulau Pisang. However, the management of Pulau Pisang should remain with Singapore.

In 2002, there were more calls urging the Malaysian government to develop the island and to review and alter the provisions of the agreement signed by the Sultan of Johor almost 113 years ago ("Pulau Pisang won't be another Batu Puteh," 2008). In order to ascertain Malaysia's sovereignty over the island, the lighthouse keepers from Singapore needed to get their passports stamped at Kukup immigration in Johor before heading to Pulau Pisang. Before 2002, there was no such requirement. Nevertheless, the fact that Pulau Pisang Light is still exclusively managed by Singapore shows that Malaysia has yet to have full sovereignty over Pulau Pisang.

\section{Methods of Territorial Acquisition under International Law}

International law dictates that a state may acquire territory in a number of ways, among others, through prescription and cession (Aust, 2005). A state may acquire sovereignty over a certain territory if the sovereignty is transferred or ceded by the sovereign to another (Rusli \& Mazlan, 2013). The Sultan of Johor has, through the 1900 Agreement, ceded in perpetuity part of its territory (where the lighthouse, the road leading to the lighthouse and the lighthouse jetty are located) to the British government of Singapore (Rusli \& Mohamad, 2013). This is the reason why the lighthouse is still being managed by the MPA even though Pulau Pisang is under Malaysia's sovereignty.

In addition, under international law, prescription refers to acquisition of sovereignty by way of actual exercise of sovereignty, maintained for a reasonable period of time, and is effected without objection from any states (Kaczorowska, 2010). Singapore's management of Pulau Pisang has taken place since 1900 and it 
continues till now without persistent objection by the Malaysian authorities (Rusli \& Mohamad, 2013).

\section{Pulau Sipadan and Ligitan}

In deciding the Malaysia-Indonesia dispute over Pulau Sipadan and Ligitan, the International Court of Justice (ICJ) looked at the case based upon the concept of 'effective occupation' (International Court of Justice (ICJ), 2004). As early as 1914, Great Britain took steps to regulate and control the collection of turtle eggs on Ligitan and Sipadan without any clear objection from the government of the Dutch East Indies (International Court of Justice (ICJ), 2008). These activities were continued by the independent State of the former British North Borneo, Sabah, when it joined Malaysia in 1963, again, without persistent protest by its successor State, Indonesia (Hsien-Li, 2010). As a result, the ICJ awarded both these islands to Malaysia on the basis of effective occupation displayed by the Malaysia's predecessor (the British) and the absence of any other superior title (Case Concerning Sovereignty over Pulau Ligitan and Pulau Sipadan (Indonesia/Malaysia), 2002).

\section{Singapore's Management of Pulau Pisang Light}

By referring to the scenario of Pulau Pisang Light, it is clear that Singapore has been actively engaged in the management of the lighthouse without consistent objection by Malaysia ("Pulau Pisang Light," 2012). If this would continuously take place, it might not be too surprising in the future if Malaysia's total sovereignty over Pulau Pisang would be put in dispute, and Singapore might want to put its claim over the area on the island where the lighthouse is located. Malaysia could not afford to have its other islands to undergo the Pedra Branca's experience.

\section{Conclusion}

It has been five years since the judgement on Pedra Branca was made, and it still is haunting Malaysia. It is indisputable that Singapore has clearly made remarks recognising Malaysia's sovereignty over Pulau Pisang. However, how could a country be positively sure of its sovereignty over its own territory if part of it is manned by a foreign State? Therefore, the agreement entered into by the Sultan of Johor and Sir Sweetenham back in 1900 should be reviewed and the control over Pulau Pisang Light should be rightfully handed over to the Marine Department of Malaysia.

At the same time, Malaysia should develop Pulau Pisang into a fishery or a tourist island to ensure Malaysia's ownership over Pulau Pisang remains intact. 
Indeed, Pulau Pisang belongs to Malaysia, and the Malaysian authorities should take any means necessary to ensure this entire island remains in totality under Malaysia's sovereignty.

\section{References}

Aust, A. (2005). Handbook of international law. Cambridge: Cambridge University Press.

Case concerning sovereignty over Pulau Ligitan and Pulau Sipadan (Indonesia/Malaysia). (2002). Retrieved from http://www.icj-cij.org/docket/files/102/7714.pdf.

Ghani: Malaysia has proof of Pulau Pisang ownership. (2008). The Star. Retrieved from, http://news.asiaone.com/News/AsiaOne+News/Malaysia/Story/A1Story20 080527-67200.html

Hsien-Li, T. (2010). Notes case concerning sovereignty over Pedra Branca/Pulau Batu Puteh, Middle Rocks and South Ledge (Malaysia/Singapore. Singapore Year Book of International Law and Contributors, 2008(12).

International Court of Justice (ICJ). (2004). Case concerning sovereignty over Pedra Brancal Pulau Batu Puteh, Middle Rocks and South Ledge (Malaysia/ Singapore): Memorial of Singapore. Retrieved from http://www.icjcij.org/docket/files/130/14133.pdf

International Court of Justice (ICJ). (2008). Sovereignty over Pedra Branca/Pulau Batu Puteh, Middle Rocks and South Ledge (Malaysia/Singapore). Retrieved 6 September 2009, from http://www.icj-cij.org/docket/files/130/14492.pdf? PHPSESSID=e5dc0baf91086da004883db261c90796

Kaczorowska, A. (2010). Public international law (4th ed.). Routledge.

Lathrop, C. (2008). Sovereignty over Pedra Branca/Pulau Batu Puteh, Middle Rocks and South Ledge (Malaysia/Singapore). The American Journal of International Law, 102.

Pulau Pisang Light. (2012). Retrieved from, http://www.lighthousedigest.com/ digest/database/uniquelighthouse.cfm?value $=3700$

Pulau Pisang to be gazetted as part of Johor. (2010). New straits times. Retrieved from, http://news.asiaone.com/News/AsiaOne+News/Malaysia/Story/A1Story20 100710-226224.html

Pulau Pisang won't be another Batu Puteh. (2008). New straits times. Retrieved from, http://archive.is/GoLV4

Rusli, M. H. b. M. (2012a). The application of transit passage regime in straits used for international navigation: A study of the Straits of Malacca and Singapore. Asian Politics \& Policy, 4(4), 549-569. 
Rusli, M. H. b. M. (2012b). Balancing shipping and the protection of the marine environment of straits used for international navigation: A study of the Straits of Malacca and Singapore. University of Wollongong, Wollongong.

Rusli, M. H. b. M., \& Mazlan, M. A. b. (2013). Sultan of Sulu's Sabah claim: A case of 'long-lost' sovereignty? RSIS Commentary, 043(2013).

Rusli, M. H. M., \& Mohamad, R. (2013). Singapore lighthouse on our island. The Sundaily. Retrieved from, http://www.thesundaily.my/node/217352

Ryan, N. J. (1967). The making of modern Malaysia: A history from earliest times to 1966. Kuala Lumpur: Oxford University Press 1967.

Singapore has no right to expand area around Pulau Pisang, says Johor MB. (2008). The star. Retrieved from, http://news.asiaone.com/News/AsiaOne\%2BNews/ Malaysia/Story/A1Story20080810-81554.html

Singapore Parliament (Special Parliament Highlights, 9 May 2005). (2005). Retrieved from, http://archive.is/xStcP. 